\title{
Satellite remote sensing for identification of solar potential sites in Pakistan
}

\author{
Romana Basir $^{1}$, Neelam Aziz ${ }^{1}$, Sheikh Saeed Ahmad ${ }^{1 *}$, Abdul Wahid ${ }^{2}$ \\ ${ }^{I}$ Department of Environmental Sciences, Fatima Jinnah Women University, Rawalpindi, Pakistan \\ ${ }^{2}$ Department of Environmental Sciences, Bahauddin Zakariya University, Multan, Pakistan \\ *Corresponding author E-mail: drsaeed@fjwu.edu.pk
}

\begin{abstract}
Renewable energy sources and technologies have the potential to provide solutions to the long-standing energy problems being faced by the developing countries like Pakistan. Pakistan is endowed with various renewable energy resources such as solar, hydal, wind, biofuel and geothermal. It can earn dividends if these resources are explored, exploited and developed. Pakistan lies in an area of one of the highest solar insulation in the world. The aim of this paper was to identify the areas receiving maximum solar radiation in Pakistan by studying the cloud cover on Pakistan in June, July and August (Monsoon period having maximum clouds) in 2005-2009 and highlighting the use of Remote Sensing in Harnessing the renewable energy resources. The results indicated that Multan and Dera Gazi Khan had the minimum cloud cover on both seasonal and yearly basis. Many locations in Baluchistan, Punjab and Sindh province (Costal Area) also have a great potential for solar energy. This vast potential can be exploited to overcome the energy shortage as the promotion, management and deployment of indigenous energy resources is an obligatory requirement to address the climate change, energy security and sustainable development issues.
\end{abstract}

Keywords: Solar Energy; Cloud Cover; Remote Sensing; Geographic Information System; Pakistan.

\section{Introduction}

One of the most important and contentious issues of our time is energy resource utilization $[1,2,3,4,5,6]$. Energy supplies are required to improve the agricultures' infrastructure, roads, transport, industry and construction of building to accelerate the economic development of the country. Pakistan is facing the acute challenge of energy deficiency due to huge increase in demand, expansion in industrialization, increment in population growth rate, high cost of energy imports, poor management of energy resources, lacking plans and devoid in implementation of policies concerning energy $[7,8,9]$.

In 2007-08, 62.8 MTOE (Million Tons of Oil Equivalent) were the total supplies in energy. Out of which gas contributes to about $48.5 \%$, oil $30 \%$, nuclear and hydel $13.7 \%$ and coal $7.3 \%$. While the energy demand of the country for year 2007-2008 was 73 MTOE, and 17 MTOE were imported to fill this energy gap. In this scenario of energy supply, the total contribution of renewable energy is very low (fractions of percentage) indicating an ignored sector of energy/power generation. The country should must utilize its vast natural resources those are renewable in order to avoid the worst situation in the coming years [10]. Pakistan is blessed with huge spectrum of al renewable energy sources with high potential including conventional as well as non-conventional which have not been sufficiently explored, employed or developed.

Out of range of renewable energy resources, in coming years one of the cleanest, powerful, cheap, safe and virtually inexhaustible energy source upon which the world can depend is solar energy [6, 11, 12, 13, 14, 15, 16]. Global potential of solar energy is 3,000,000 TWh/y [17]. From geographical point of view, Pakistan lies in an area which is included in one of worlds' areas with greatest solar insulation. Pakistan receives $5.5 \mathrm{KW} / \mathrm{m}^{2}$ of solar radiation on average and almost greater than 300 clear days per annum. The estimated solar energy potential in Pakistan is over 100,000 MW [18]. In the world total electricity generation by Concentration Solar Power (CSP) was $436 \mathrm{MW}$ at the end of 2008. Numbers of projects are under pipeline which will add 1,000 MW in Spain, 7,000 MW in USA by 2011, also 10,000 GW in Spain by 2017 [13, 14]. In accordance to Global CSP outlook 2009, 7\% of projected world's energy requirement could be fulfilled by CSP in 2030 and by 2050 it would increase to full quarter under an advance industry development scenario, with high energy efficiency [13]. Currently Pakistan is struggling to import energy resources 
from Kyrgyzsta, Central Asia, Tajikistan and gas from Qatar, Iran and Turkmenistan. Undoubtedly precedence must be given to such projects but still the utilization of resources on domestic scale is vital as well to encourage self reliance for country's self reliance which is important for economic development and also save foreign exchange [10]. Number of studies has been conducted regarding the assessment of solar energy potential in Pakistan that must be considered while taking the decision regarding domestic energy resource exploration [10, 11, 19, 20, 21, 22, 23, 24]. Mapping of resources and demand on spatial and temporal scale can be easily done by using Geographic Information system (GIS) along with Advanced Remote Sensing (ARS). The spatial data regarding the resource availability and demand in an area would help in energy planning at local, regional and global level. GIS and RS helps in identifying and quantifying the elements affecting the availability of solar energy [25]. Number of studies has been conducted regarding the assessment of solar energy potential by using RS and GIS [20, 21, 25, 26, 27, 28, 29, 30, 31, 32, 33, 34, 35, 36].

The aim of the study was to identify the areas receiving maximum solar radiation in Pakistan and highlighting the use of satellite technology in harnessing renewable energy sources. In this study cloud cover on Pakistan was estimated by using satellite images of June, July and August of year 2005-2009 in order to identify the potential concerning solar energy in Pakistan.

\section{Study area}

Pakistan is located between longitude $62^{\circ}$ and $75^{\circ}$ East and latitude $24^{\circ}$ and $37^{\circ}$ North shown in figure 2.1 . Iran is located in the west, India is located in the east, Afghanistan in the north-west, China in the north and in the south there is the Arabian Sea. The total area of Pakistan is estimated to bebe 8, 03,950 sq. km. The country is categorized into four provinces namely Khyber Pakhtunkhwa, Sindh, Baluchistan and Punjab [22, 37]. Pakistan receives high intensity solar radiations due to its unique geographical location and favorable climatic conditions [23]. The province of Punjab is generally flat, alluvial plain dominating five major rivers especially in upper region eventually combining the Indus River flowing in south direction to Arabian Sea. Sindh is bounded on the east by the Thar Desert and the Rann of Kutch and on the west by the Kirthar range and the Baluchistan Plateau is predominantly an arid tableland, encircled by dry mountains [22].

\section{Materials and methods}

\subsection{Data collection}

Satellite images were used in this study to identify the solar potential sites in Pakistan. These images have lot of other applications in geology, agriculture, forestry, warfare, intelligence and regional planning. They can be either in visible colors or nay other spectra. Elevation maps are also included usually created by radar imaging. In this study satellite data were taken from NOAA (National Oceanic and Atmospheric Administration) (table 1). NOAA data focused on the condition of the oceans and the atmosphere and data freely available on their website (www.noaa.gov). Advanced Very High Resolution Radiometer images of June, July and August of year 2005-2009 were selected for this study. A crosstrack scanning system namely Advanced Very High Resolution Radiometer (AVHRR) having five spectral bands with a resolution of $1.1 \mathrm{~km}$ and a frequency of scanning earth twice a day (0230 and 1430 local solar time). June, July and august data is used because these are monsoon month and have maximum cloud in these month. Precipitation data of selected months and districts has been collected from Pakistan Metrological Department.

Table 1 Characteristics of data used in study

\begin{tabular}{|c|c|c|c|c|c|}
\hline \multirow[t]{2}{*}{ Data } & \multirow[t]{2}{*}{ Source } & \multirow{2}{*}{$\begin{array}{l}\text { Data } \\
\text { characteristics }\end{array}$} & \multicolumn{3}{|c|}{ Dates used in Study } \\
\hline & & & Years & Months & Days \\
\hline $\begin{array}{l}\text { NOAA AVHRR } \\
\text { HRPT }\end{array}$ & www.class.ncdc.noaa.gov & Bands 5 & $\begin{array}{l}2005- \\
2009\end{array}$ & $\begin{array}{l}\text { June, July, } \\
\text { August }\end{array}$ & 30 \\
\hline $\begin{array}{l}\text { Pakistan Districts } \\
\text { boundaries }\end{array}$ & $\begin{array}{l}\text { http://pakgis.blogspot.com/2009/03/dist } \\
\text { rict-boundaries-of-pakistan.html }\end{array}$ & Vector format & & & \\
\hline
\end{tabular}

\subsection{Data interpretation and analysis}

ENVI and ArcGIS are main software packages that are employed for interpretation and analysis of satellite imagery. 


\subsubsection{Data Processing}

Satellite Images were processed by using ENVI image processing software through following procedures;

- $\quad$ Geo referencing

- $\quad$ Enhancement

- $\quad$ Selection of Area of Interest for Classification (ROI)

- $\quad$ Supervised Classification (Maximum likelihood method)

- $\quad$ Subset (using Pakistan boundaries)

- $\quad$ Vector Conversion

- $\quad$ Composite (Monthly Maps) (figure 1)

\subsubsection{Data analysis}

In order to find out least cloudless area, GIS analysis has been performed by using Arc Tools of ArcGIS analysis. UNION option was found most appropriate for combing cloud vector layers of different years and resultant UNION layer shows areas with and without clouds. Final step involve to overlay the Pakistan district vector layer on each UNION layer, i.e., June 2005-2009, July 2005-2009 \& August 2005-2009 which provides location of least cloudless districts in Pakistan.

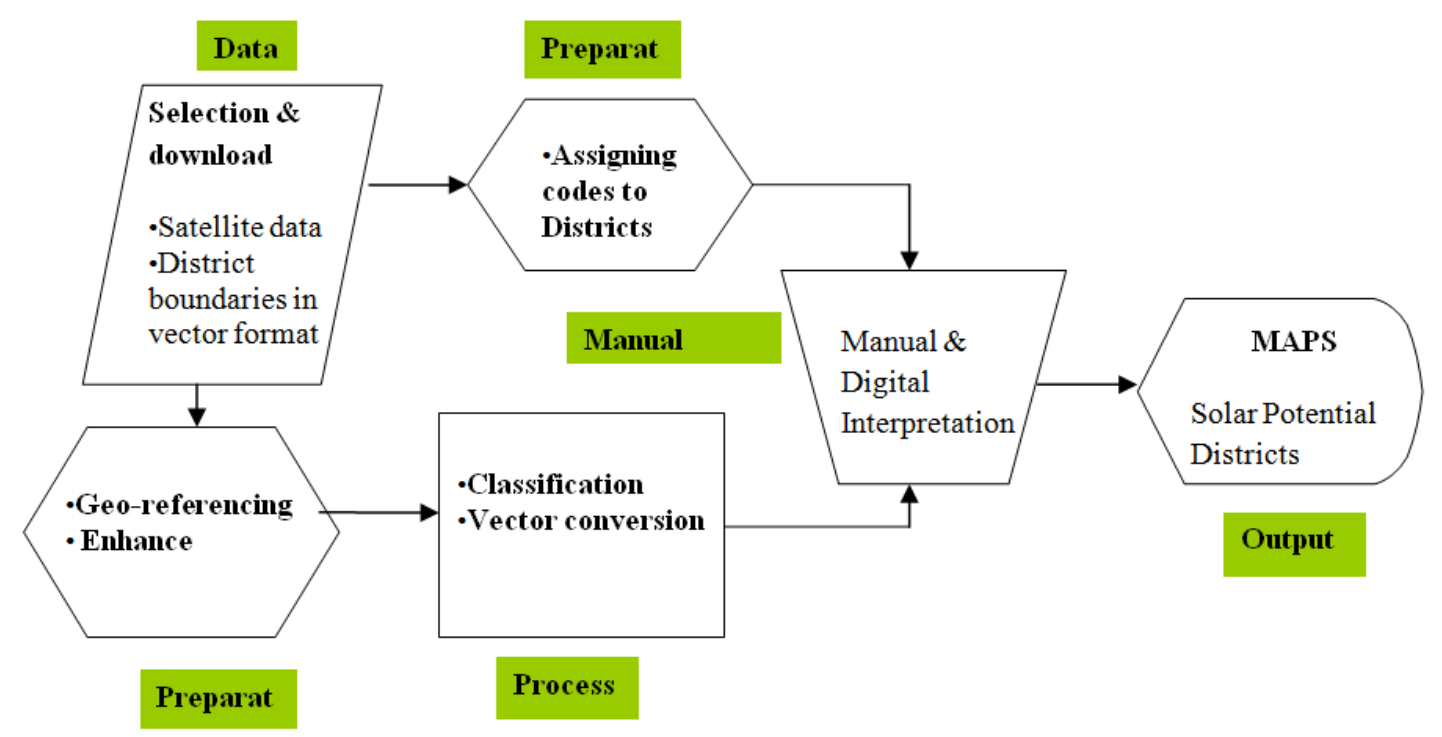

Figure 1: Workflow Schematic

\section{Results and discussion}

Solar energy is one of the cheap, pollution free, inexhaustible renewable energy resource $[6,14,15,16]$. Long term detailed knowledge of potential sites is required for the development of this energy resource, in order to establish the solar houses at a large scale. Regions of the earth located on solar belt which is between the latitude $40^{\circ} \mathrm{N}$ and $40^{\circ} \mathrm{S}$ supposed to receive the maximum solar radiation are good to established the large scale CSP insulation [13, 25]. Pakistan as being located on solar belt is suitable for harvesting and development of solar energy. The main objective of this study was to locate solar potential sites of Pakistan using images taken from different satellite. GIS and Remote sensing based integrated approach has been adopted in this study to evaluate maps for locating "least cloud areas" in Pakistan which can be used as a potential site for solar energy generation. Different maps were generated on season (June, July and August) as well as on yearly base (2005 to 2009). Figures showed the average clouds over Pakistan in months of June, July and August for five years from 2005 to 2009.

\subsection{Yearly based overlay maps}

The following images (figure 2) showed the maximum cloud cover over Pakistan during June, July and August from 2005-2009. 

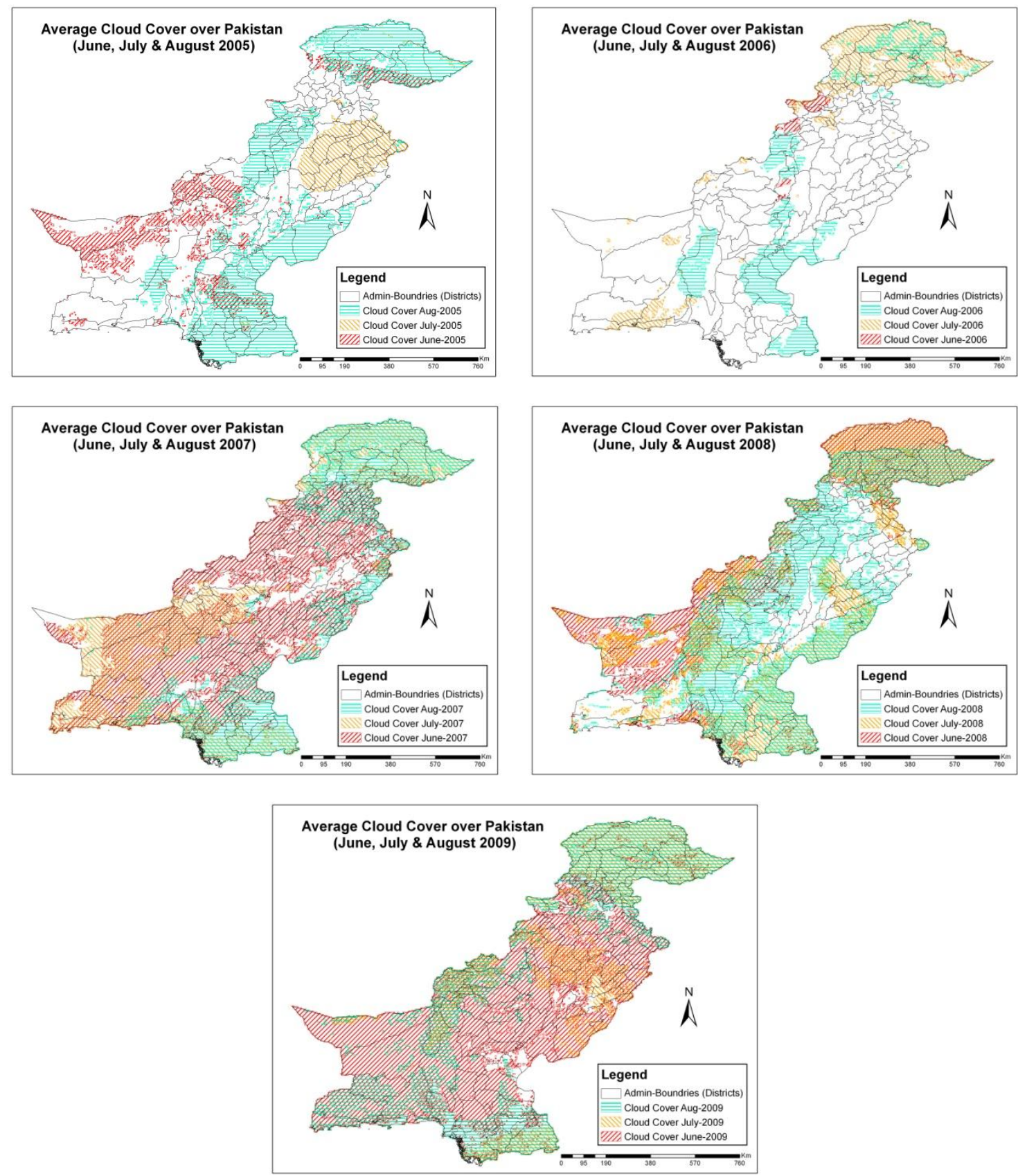

Figure 2: Average cloud cover over Pakistan in 2005 to 2009

\subsection{Yearly based union maps}

By using UNION option available in ArcGIS for combining cloud coverage of each year give resultant map which indicated the areas with least cloud cover in 2005-2009 (figure 3). 

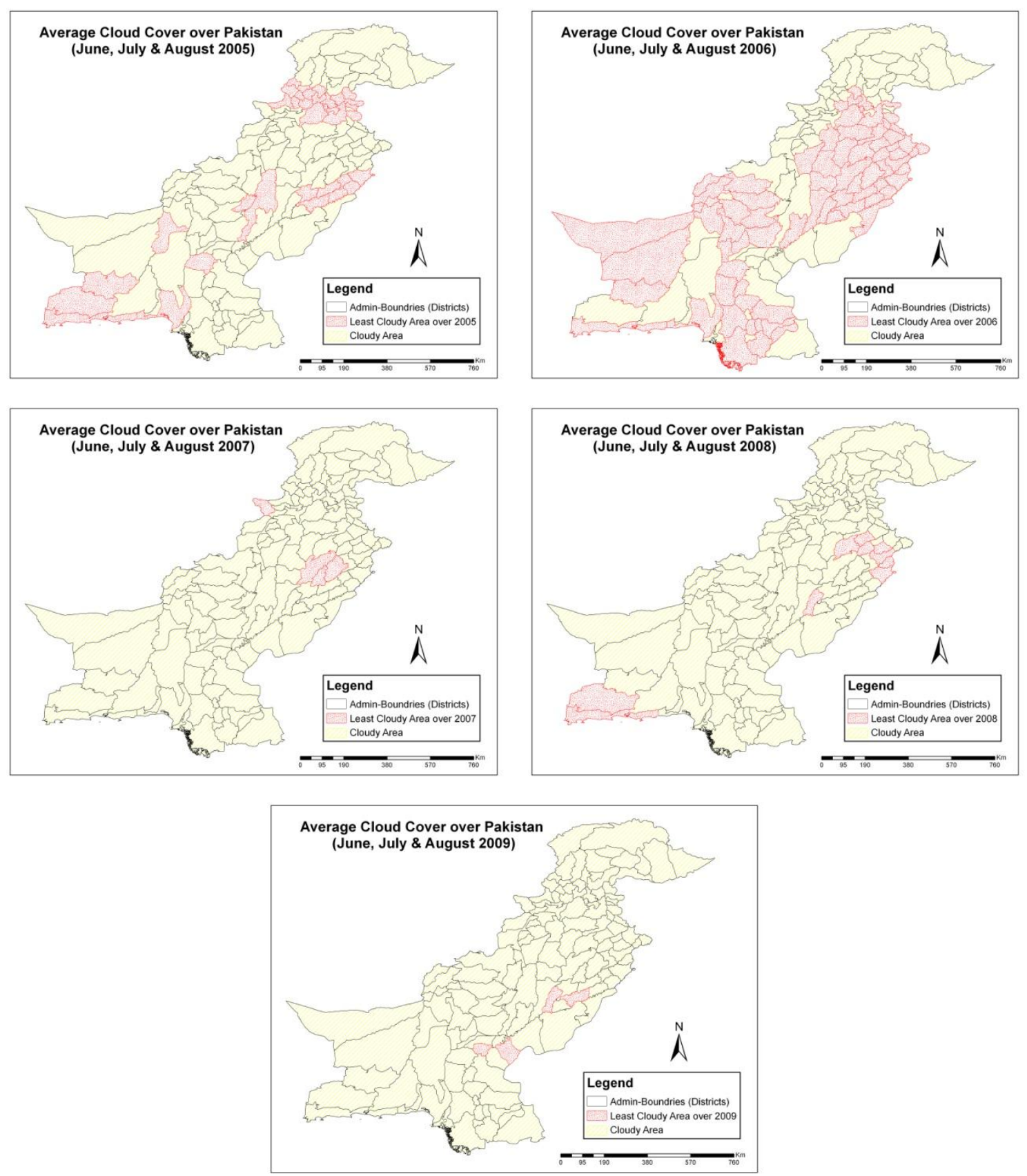

Figure 3: Average cloud cover over Pakistan in 2005-2009 (Union Map)

Least cloud areas found in yearly based map are mentioned in table 2.

\begin{tabular}{lll}
\hline Ynalysis & Table 2: Locations of least cloud coverage (yearly bases) \\
\hline Yearly bases & Location of Least cloud coverage (district) \\
& $\begin{array}{l}\text { Makran, Kalat, Dera Ghazi khan, Zhob, Multan, Lahore, Rawalpindi, Azad } \\
\text { Kashmir, Hazara, Islamabad, Mardan, Malakand, FATA, Peshawar. }\end{array}$ \\
\cline { 2 - 3 } 2005 & $\begin{array}{l}\text { Quetta, Kalat, Makran, Hyderabad, Mirpurkhas, Sukkur, Larkana, Nasirabad, } \\
\text { Sibi, Zhob, DGK, Multan, Bahawalpur, Lahore, Faisalabad, Sarghoda, } \\
\text { Gujranwala, AzadKashmir, Rawalpindi, Hazara, Peshawar, Mardan. }\end{array}$ \\
\hline 2007 & FATA, Faisalabad. \\
\hline 2008 & Makran, Multan, Lahore, Dera Ghazi Khan, Gujranwala, Sarghoda, Peshawar. \\
\hline
\end{tabular}


Minimum cloud cover was found in 2006, while maximum was found in 2009. Most the above mentioned locations were found in Punjab, Baluchistan and Sindh Province. In Pakistan average daily solar insulation amount is estimated to be approximately $5-7 \mathrm{KWh} / \mathrm{m}^{2} /$ day means available natural energy resource input is $18-25 \mathrm{MJ} / \mathrm{m}^{2} /$ day that can be used for power generati10on. Particularly the Northeastern part of Sind and southwestern province of Baluchistan provides the most favorable conditions for harnessing solar energy. In these areas sun shine between

$6-8 \mathrm{~h}$ daily $[10,22]$. Baluchistan has an average daily global insulation of $19-20 \mathrm{MJ} / \mathrm{m}^{2}$ a day $(1.93-2.03 \mathrm{MWh}$ per $\mathrm{m} 2$ in a year) with annual mean sunshine duration of $8-8.5 \mathrm{~h}[22,38]$. Monthly solar radiation averages of capitals of four provinces of Pakistan were measured, Lahore 2.8-6.27, Peshawar 2.4-6.35, Karachi 3.39-6.31, and Quetta 3.6-7.65 [39]. In 2005, 2006 and 2008 some of the coastal areas were identified as favorable sites for harvesting solar energy as the cloud cover was not present. According to a study conducted in Karnataka, the higher global solar radiation was found in the coastal part of Karnataka favorable for harvesting solar power. Maximum global radiation according to potential analysis was founded in Uttara Kannada and Dakshina Kannada [25, 40].

\subsection{Seasonally based overlay maps}

Similarly seasonally based overlay maps were created as shown in figure (4) which shows the maximum cloud cover of Pakistan.
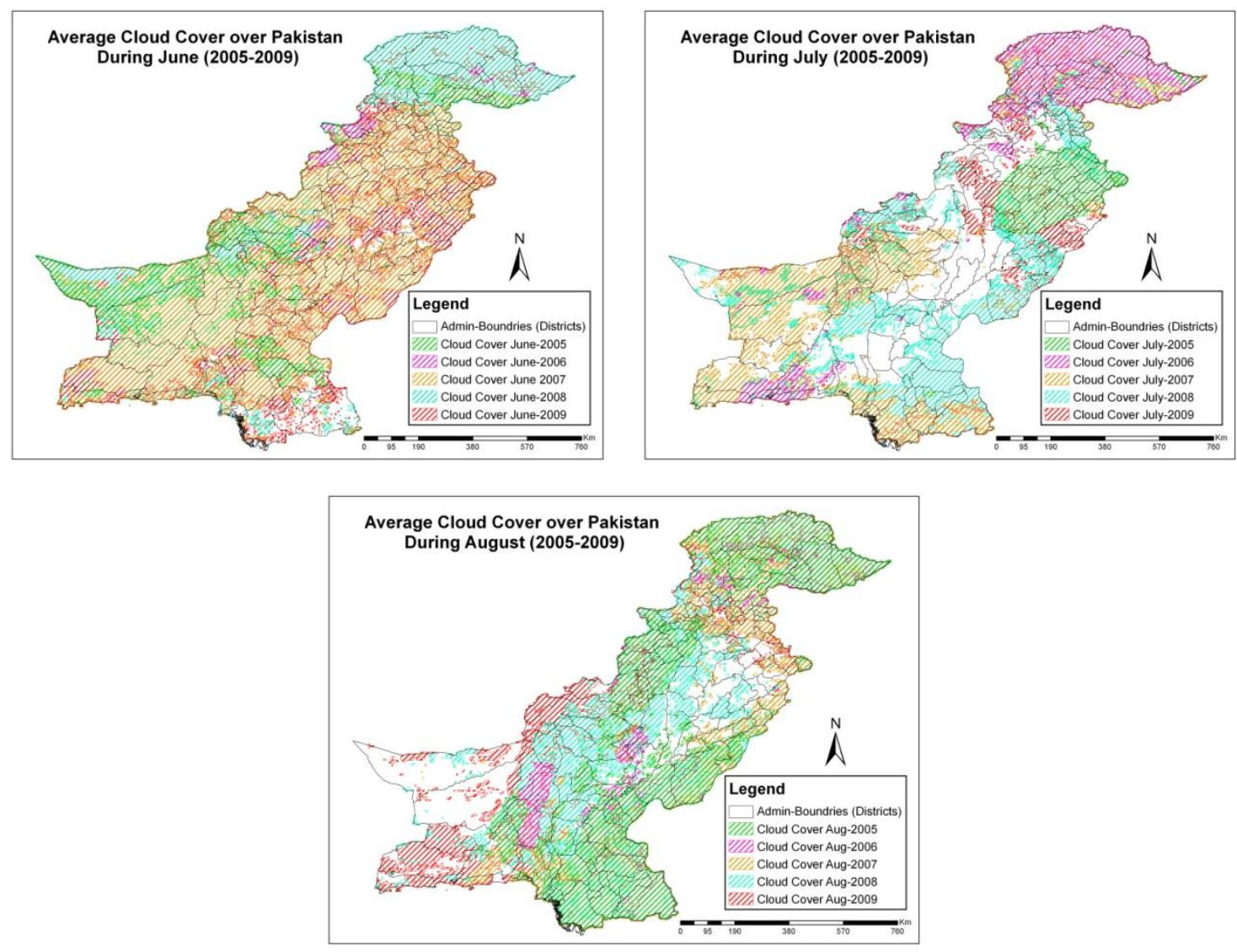

Figure 4: Average cloud cover over Pakistan in June to August

\subsection{Seasonally based union maps}

Same procedure is done for union maps by using ArcGIS tool and finds the least cloudy areas in the month of June, July and August based on seasonally results (figure 5). 

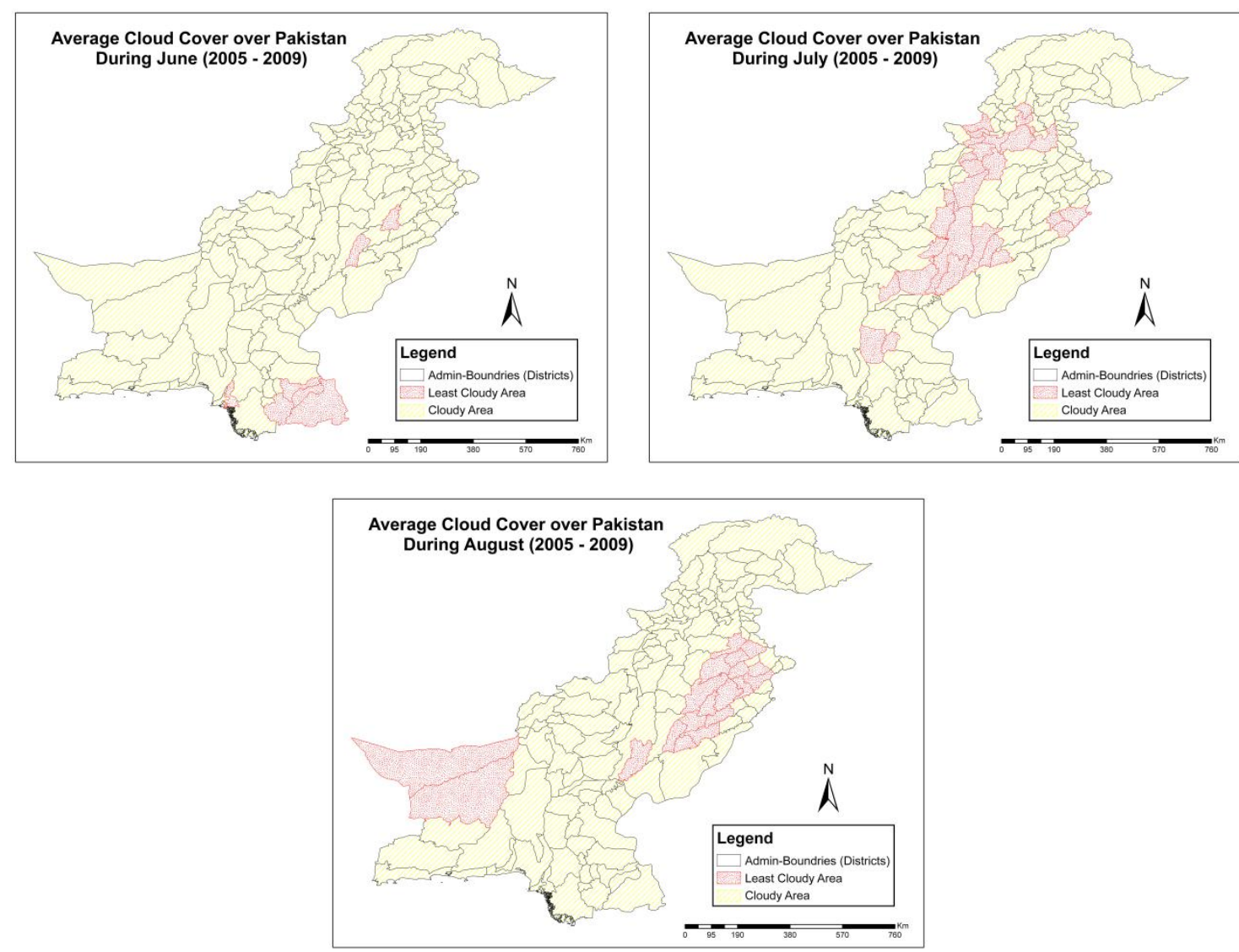

Figure 5: Average cloud cover over Pakistan in June to August (Union Map)

Least cloud areas found in seasonally based map are mentioned in table 3.

Table 3: Locations of least cloud coverage (seasonally bases)

\begin{tabular}{lll}
\hline Analysis & Year & Location of Least cloud coverage(district) \\
\hline Seasonal bases & June (2005 to 2009) & Mirpurkhas, Hyderabad, Faisalabad, Multan. \\
\cline { 2 - 3 } & July (2005 to 2009) & $\begin{array}{l}\text { Hyderabad, Sukkur, Nasirabad, Sibi, DGK, Multan, Zhob, Dera } \\
\text { ismailkhan, Bannu, Sarghoda, Kohat, FATA, Islamabad, Hazara, Lahore. }\end{array}$ \\
\cline { 2 - 3 } & August (2005 to 2009) & Quetta, Kalat, Dera Ghazi Khan, Multan, Faisalabad, Gujranwala, Lahore. \\
\hline
\end{tabular}

Figure 4 indicated that least cloud cover was found in July while maximum in June. According to figure 5 most of the sites with no cloud cover in June, July and August 2005-2009 located in Punjab, Baluchistan and Sindh province. Empirical relationship was used to determine the direct and diffuse radiation intensities for 40 locations of Pakistan [41] and satellite APT images based contour map of Pakistan solar radiation intensities [42] indicated that approximately half of Pakistani areas have favorable condition to establish large scale solar utilities [23]. Pakistan solar climate was studied in detailed by Raja [43] to identify the solar potential of the country. The mean annual values of solar radiation insulation ranges between $15-21 \mathrm{MJ} / \mathrm{m}^{2}$. Major part of Pakistan receives insulation about $19-20 \mathrm{MJ} / \mathrm{m}^{2}$, while in extreme Northern Areas values ranges between $15-17 \mathrm{MJ} / \mathrm{m}^{2}[44]$.

Finally the results of seasonal and yearly maps were then combined by using GIS tool and the figure (6) shows the most suitable location for potential solar site in Pakistan based on least cloud coverage during five years in monsoon season. Finally the table shows the most potential site of Pakistan which was generated by using figure 6 shown in table 4 . 


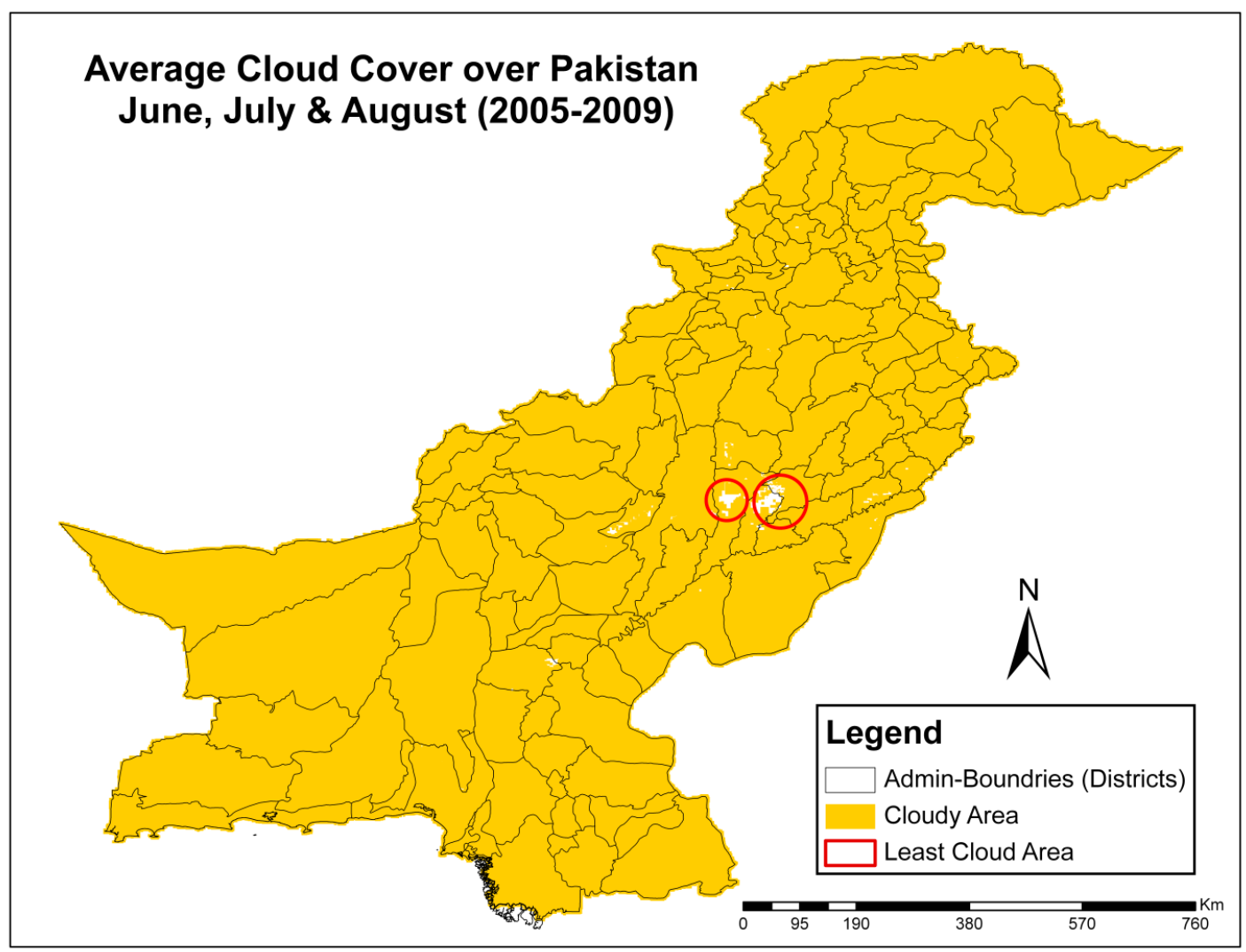

Figure 6: Average cloud cover over Pakistan from June to August (2005-2009)

Table 4: Location of solar potential sites of Pakistan
(i) Overall best location (yearly bases)
(i) Multan and Dera Ghazi Khan
(ii) Overall best location (seasonally based)
(ii) Multan and Dera Ghazi Khan

The present study highlighted the cloud cover and solar potential sites of Pakistan over last five years. The results indicated that Dera Gazi Khan and Multan have the maximum potential solar sites in whole Pakistan. Both of them lie in Punjab province. In Punjab province Cholistan desert has been quite favorable for solar energy harvesting [45]. Whereas Quetta is selected to be a city receiving highest of solar radiation [46]. According to the status and outlook of solar energy use in Pakistan, there is a vast potential of electricity generation from solar energy in hilly northern area and the south and western deserts [22]. 300 household were electrified by PV power generation of 200KW by AEDB in Districts of Rawalpindi, D.G. Khan (Punjab), Turbat/Kalat (Baluchistan), Tharparkar (Sindh) and Kohat (N.WF.P). More than 500 houses, schools, mosques were electrified by PCRET with PV power generation of $80 \mathrm{KW}$ total generation capacity [10].

In spite of the high potential of solar energy in Pakistan, there are many reasons for not utilizing this huge resource to fulfill the countries energy demand. One of the major reasons is that people think that this technology is expensive. In comparison with conventional power system, solar power system is frequently considered too much costly. This is because the single unit photovoltaic cost is compared with the available power at the door step. True picture of cost analysis is not clearly depicted by this comparison. In the national policy, comparison of some mega project (fixed and running) cost with solar projects was done. For example, the observed cost of Ghazi Barotha Dam will be 118 million Rs per MW, while the cost of thermal power system will be 70 million Rs per MW. This major saving is in construction. While both of the system will have almost same operational and maintenance cost [47, 48]. Other reasons include the lack of awareness at institutional, investment and public level.

Country should exploit the solar energy at a large scale, which will in return allow saving considerable amount of fossil fuel utilization, and that will aid in the improvement of environmental quality and peoples' living standards and also helps in reducing the massive load on economy of Pakistan. Well planned and intensive efforts are required to be adopted by the governmental institutions in order to prop up the utilization of solar energy and increase the awareness among the masses and investors about its associated benefits. 


\section{Conclusion}

In spite of having a huge potential of energy resources, Pakistan still remains an energy scarce country and has to heavily depend on imports to fulfill its energy demand. The major goal of this study was to identify the solar potential sites in Pakistan by evaluating the cloud cover in monsoon months (June, July and August) in 2005-2009 and accentuate the importance of remote sensing in identifying the renewable energy resources. Government should take initiatives to promote the exploitation of solar energy throughout the nation to overcome its energy needs that will help in saving the money and fossil fuel which will in turn helps in improving the economy of the country.

\section{References}

[1] FD (Finance Division), Economic survey 2000-2001: Government of Pakistan, Economic Adviser's Wing, Finance Division, Islamabad, (2001).

[2] R. Pelc, R.M. Fujita, Renewable energy from the ocean, Marine Policy, Vol. 26, No. 6, (2002), pp. $471-479$.

[3] N.A. Zaigham, Z.A. Nayyer, Prospects of renewable energy sources in pakistan, Proceedings of COMSATS Conference 2004 on Renewable Energy Technologies and Sustainable Development, (2005), pp. 65-81.

[4] M. Munir, Pakistan's Quest for Energy Security, Pakistan Observer, 20 May 2006.

[5] K.N.A. Maulud, O.A. Karim, K.M.D. Sopian, Z. Darus, E.E.M. Raml, Identification a potential wave energy location in Malaysia using GIS, Proceedings of WSEAS International Conference on Mathematical Methods, Computational Techniques, Non-Linear Systems, Intelligent Systems, (2008), pp. 426-430.

[6] Z. Ramedani, M. Omid, A. Keyhani, Modeling solar energy potential in Tehran province using Artificial Neural Networks, International Journal of Green Energy, Vol. 10, (2013), pp. 427-441.

[7] M. Balat, Security of energy supply in Turkey: Challenges and solutions, Energy Conservation and Management, Vol. 51, No. 10, (2010), pp. 1998-2011.

[8] Sarı, K. Kaygusuz. Renewable energy potential and utilization in Turkey, Energy Conservation and Management, Vol. 44, No. 3, (2003), pp. 459-478.

[9] M.G. Douggar, Energy situation in Pakistan: options and issues, Renewable Energy, Vol. 6, No. 2, (1995), pp.151 157.

[10] M.A. Sheikh, Renewable energy resource potential in Pakistan, Renewable and Sustainable Energy Reviews, Vol. 13, No. 9, (2009), pp. 2696-2702.

[11] F. Ahmad, Thesis: Solar radiation studies at Karachi Pakistan. Pakistan Research Repository: Physics, (1898).

[12] M. Eck, Rueda, S. Kronshage, C. Schillings, F. Trieb, E. Zarza, Solar thermal power plants for the Spanish electricity market, International Journal of Energy Technology and Policy, Vol. 5, No. 3, (2007), pp. 261-27.

[13] Richter, S. Teske, J.A. Nebrera, Concentrating solar power - global outlook 2009, Greenpeace, Solar Paces and ESTELA, (2009), pp. 1-86.

[14] Jain, R. Mehta, K. Susheel, Mittal Modeling impact of solar radiation on site selection for solar PV power plants in India, International Journal of Green Energy, Vol. 8, No. 4, (2009), pp. 486-498.

[15] T. Khatib, A. Mohamed, M. Mahmoud, K. Sopian, Modeling of daily solar energy on a horizontal surface for five main sites in Malaysia, International Journal of Green Energy, Vol. 8, No. 8, (2011), pp. 795-819.

[16] M.H. Al-Shamisi, A. H. Assi, H.A-N. Hejase, Artificial neural networks for predicting global solar radiation in Al Ain City - UAE, International Journal of Green Energy, (2012), DOI: 10.1080/15435075.2011.641187

[17] F. Trieb, C. Schillings, M. O’Sullivan, T. Pregger, C. Hoyer-Klick, Global potential of concentrating solar power, Solar Paces Conference Berlin, September, (2009), 1-11.

[18] Z.I. Zaid, Pakistan Renewable energy report. Asian and Pacific Centre for transfer of technology of the United Nations - Economic and Social Commission for Asia and the Pacific (ESCAP), (2009), pp. 1-53.

[19] I.A. Raja, Insulation sunshine relation with site elevation and latitude, Solar Energy, Vol. 53, No.1, (1994), pp. 53-56.

[20] M.D.I. Rafiqul, R.H.B. Exell. Solar radiation mapping from satellite image using a low cost system, Solar Energy, Vol. 56, No. 3, (1996), pp. 225-237.

[21] A.Q. Malik, A. Mufti, H.W. Hiser, N.T. Veziroglu, Solar mapping of Pakistan using visible images from geostationary satellites, Renewable Energy, Vol. 13, No. 1, (1998), pp. 1-16.

[22] U.K. Mirza, M.M. Maroto-Valer, N. Ahmad Status and outlook of solar energy use in Pakistan, Renewable and Sustainable Energy Reviews, Vol. 7, No. 6, (2003), pp. 510-514.

[23] M.H. Sahir, A.H. Qureshi, Assessment of new and renewable energy resources potential and identification of barriers to their significant utilization in Pakistan, Renewable and Sustainable Energy Reviews, Vol. 21, No.1, (2008), 290-298.

[24] M.A. Chaudhry, R. Raza, S.A. Hayat, Renewable energy technologies in Pakistan: Prospects and challenges, Renewable and Sustainable Energy Reviews, Vol. 13, No. (6-7), (2009), pp. 1657-1662.

[25] T.V. Ramachandra, Solar energy potential assessment using GIS, Energy Education Science and Technology, Vol. 18, No. 2, (2007), pp. 101114.

[26] T.D. Tarpley, Estimating incident solar radiation at the surface from geostationary satellite data, Journal of Applied Meteorology, Vol. 18, (1979), pp. 1172-1181.

[27] W. Moser, E. Raschke, Mapping of global radiation and of cloudiness from Meteosat image data, Meteorol. Rdsch., Vol. 36, (1983), pp. 3341.

[28] Cano, J.M. Monget, M. Albuisson, H. Guillard, N. Regas, L.A. Wald, method for the determination of global solar radiation from meteorological satellite data, Solar Energy, 37, (1986), pp. 31-39.

[29] Aksakal, S. Rehman, Global solar radiation in Northeastern Saudi Arabia, Renewable Energy, 17, (1999), pp. 461-472.

[30] V. Laine, A. Venalainen, M. Heikinheimo, O. Hyvarinen, Estimation of Surface Solar global radiation from NOAA AVHRR data in high latitudes, Journal of Applied Meteorology, Vol. 38, No. 12, (1999), pp. 1706-1719.

[31] S. Rehman, G.G. Saleem, Spatial estimation of global solar radiation using geostatistics, Renewable Energy, Vol. 21, (2000), pp. 583-605.

[32] Schillings, H. Mannstein, R. Meyer Operational method for deriving high resolution direct normal irradiance from satellite data, Solar Energy, Vol. 76, (2004), pp. 475-484. 
[33] S. Janjai, J. Laksanaboonsong, M. Nunez, A. Thongsathitya, (2005). A. Development of a method for generating operational solar radiation maps from satellite data for a tropical environment, Solar Energy, Vol. 78, No. 6, (2005), pp. 739-751.

[34] A.W. Azhari, K. Sopian, A. Zaharim, M.A. Ghoul, Solar radiation maps from satellite data for a tropical environment: case study of Malaysia, Proceedings of the 3rd IASME/WSEAS international conference on Energy and Environment, (2008), pp. 528-533.

[35] S. Janjai, S. Buntung, R. Wattan, I. Masiri, Mapping solar ultraviolet radiation from satellite data in a tropical environment. Remote Sensing of Environment, Vol. 114 No. 3, (2010), pp. 682-691.

[36] S. Janjai, A method for estimating direct normal solar irradiation from satellite data for a tropical environment, Solar Energy, Vol. 84, (2010), pp. 1685-1695.

[37] U.K. Mirza, N. Ahmad, T. Majeed, K., Harijan, (2007). Wind energy development in Pakistan, Renewable and Sustainable Energy Reviews, Vol. 11, No. 9, (2007), pp. 2179-2190.

[38] World Energy Council, Renewable energy in South Asia: Status and prospects. London, UK, (2000).

[39] M.S. Nasir, M.S. Raza. Wind and solar energy in Pakistan. Energy, Vol. 18, No. 4, (1993), pp. 397-399.

[40] T.V. Ramachandra, B.V. Shruth. (2007). Spatial mapping of renewable energy potential, Renewable and Sustainable Energy Reviews, Vol. 11, (2007), pp. 1460-1480.

[41] R.I. Raja, W.J. Twidell, Distribution of diffuse and direct insolation over Pakistan, Solar and Wind Technology, Vol. 7, No. (2-3), (1990), pp. $277-292$

[42] R.K. Fawz-ul-Haq, R.Z. Siddiqui, Identifying potential solar power generation sites using satellite apt images, Advance Space Research, Vol. 14, No. 1, (1994), pp. 243-246.

[43] I.A. Raja, Assessment of solar radiation in Pakistan, Ph.D thesis, University of Strathclyde, Glasgow, U.K., (1992).

[44] I.A. Raja, M.G. Dougar, R.S. Abro, Solar energy applications in Pakistan, WREC, (1996), 1128-1131.

[45] B.M. Sukhera, Utilization of solar energy-A programme for the development of Cholistan desert, Solar Energy, Vol. 33, No. (3-4), (1984), pp. 233-235.

[46] I.Z. Syed, A. Muhammad, M.S. Nasir, (2000). Cumulative frequency distribution of solar insolation at Quetta, Pakistan, Renewable Energy, Vol. 20, (2000), pp. 83-86.

[47] Cosmi, M. Macchiato, L. Mangiamele, G. Marmo, F. Pietrapertosa, M. Salvia, Environmental and economic effects of renewable energy sources use on a local case study, Energy Policy, Vol. 31, (2003), pp. 443-457.

[48] M.A. Khan, N. Latif, Environmental friendly solar energy in Pakistan's scenario, Renewable and Sustainable Energy Reviews, Vol. 14, No.8, (2010), pp. 2179-2181. 